\title{
Forensic age assessment of asylum seekers in Finland
}

\section{Metsäniitty, Mari}

2017-01

Metsäniitty , M , Varkkola , O , Waltimo-Siren , J \& Ranta , H 2017 , ' Forensic age assessment of asylum seekers in Finland ', International Journal of Legal Medicine, vol. 131 , no. 1 , pp. 243-250 . https://doi.org/10.1007/s00414-016-1498-x

http://hdl.handle.net/10138/231997

https://doi.org/10.1007/s00414-016-1498-x

publishedVersion

Downloaded from Helda, University of Helsinki institutional repository.

This is an electronic reprint of the original article.

This reprint may differ from the original in pagination and typographic detail.

Please cite the original version. 


\title{
Forensic age assessment of asylum seekers in Finland
}

\author{
Mari Metsäniitty $^{1}$ (D) Olli Varkkola ${ }^{1} \cdot$ Janna Waltimo-Sirén $^{2} \cdot$ Helena Ranta $^{1}$
}

Received: 10 July 2016 / Accepted: 10 November 2016/Published online: 25 November 2016

(C) Springer-Verlag Berlin Heidelberg 2016

\begin{abstract}
In Finland, forensic age assessment is strictly regulated by legislation. According to the Aliens Act (301/2004) and the amendment of the Act (549/2010), the police authorities, the frontier guard authorities, and the immigration authorities have the right to refer asylum seekers to the University of Helsinki, Department of Forensic Medicine, for age assessment. These assessments are especially performed to solve if the person is of major age, the cutoff being 18 completed years. The forensic age assessment is largely based on dental development, since the special permit of the Radiation and Nuclear Safety Authority (STUK) to the Department of Forensic Medicine of the University of Helsinki, allowing the use of ionizing radiation for nonmedical purposes, includes dental and hand X-rays. Forensic age assessment is always performed by two forensic odontologists. In 2015, the total number of forensic age assessment examinations was 149 , and the countries of origin of the asylum seekers were most commonly Iraq, Afghanistan, and Somalia. The current legislation on forensic age assessment has been well received and approved. Radiological and other examinations can be performed in different parts of Finland, but the forensic odontologist at the University of Helsinki is always involved in the process and ensures joint quality standards for the forensic age assessment.
\end{abstract}

Mari Metsäniitty

mari.metsaniitty@helsinki.fi

1 Department of Forensic Medicine, University of Helsinki, P.O. Box 40, Kytösuontie 11, FI-00014 Helsinki, Finland

2 Department of Oral and Maxillofacial Diseases, University of Helsinki, P.O. Box 41, Mannerheimintie 172,

FI-00014 Helsinki, Finland
Keywords Asylum seekers · Forensic age assessment . Forensic odontology $\cdot$ Legislation $\cdot$ Radiology

\section{Introduction}

Due to wars and other conflicts around the world, the numbers of asylum seekers in recent years in industrialized countries have risen. A clear change occurred in 2003, when the number of pending asylum applications in industrialized countries reached 505,000 [1]. In the European Union (EU), the number of asylum seekers increased significantly from 626,065 in 2014 into 1,321,600 in 2015. The largest group in 2015 came from Syria. Between 2014 and 2015, the countries with the highest increase in numbers of pending applications were Germany, Hungary, Sweden, and Austria. In relative terms, the largest increase in the number of first-time applicants was, however, recorded in Finland, with a more than ninefold increase from 2014 to 2015 [2].

In 2015, EU countries received 88,700 applications from unaccompanied minors, and of all the applicant minors, $23 \%$ were unaccompanied. Among those seeking asylum in Europe, there are more males than females, and especially in the younger age groups, there is a significant gender inequality. In 2015, in the age group 14-34 years, around 80\% were male [2].

Forensic age assessments have been performed in Finland since the middle of 1990s. The first cases were related to international adoptions. In 2009, the need for forensic age assessments increased remarkably due to the rising number of immigrants and unaccompanied minor asylum seekers coming to Finland since the end of 2008. Most of the minor asylum seekers that the police authorities referred to forensic age assessment in 2009 had told that they were 15-17 years old. The legal age threshold to distinguish between a child and 
an adult is 18 years, and the main goal is to assess whether the asylum seeker has reached the age of majority. Other aspects exist as well, namely when unaccompanied minor asylum seekers arrive without documents to prove their identity, the authorities may set the age incorrectly, and sometimes, the age of a minor immigrant needs to be re-evaluated. In the situation 2009, in the absence of Finnish legislation concerning forensic age assessment, the Ministry of the Interior prepared a government's proposal for the parliament to change the Aliens Act [3]. Today, forensic age assessment is strictly regulated by legislation with the special permit of the Radiation and Nuclear Safety Authority to the Department of Forensic Medicine of the University of Helsinki, allowing the use of ionizing radiation for non-medical purposes $[4,5]$.

The purpose of the present paper is (1) to describe the unique Finnish legislation concerning forensic age assessment and the experience of how the Aliens Act (301/2004) and the amendment of the Act (549/2010 Section 6a and 6b) [4] work in practice; (2) to describe the methods of forensic age assessment used in Finland; (3) to report the number and frequency of forensic age assessments in Finland during the years 20052015; and (4) to present the results of the Finnish age assessments among asylum-seeking minors in 2015.

\section{Materials and methods}

The information was collected from the Finnish legislation texts, EU statistics, and the public statistics of asylum seekers in Finland by the immigration authorities. Concerning the results of the forensic age assessments among asylumseeking minors, the author O.V. as forensic odontologist working at the Department of Forensic Medicine, University of Helsinki, had access to the information.

\section{Legislation}

According to Aliens Act (301/2004) and the amendment of the Act (549/2010 Section 6a and 6b), the police authorities, the frontier guard authorities, and the immigration authorities have the right to refer asylum seekers to the University of Helsinki, Department of Forensic Medicine, for age assessment in case there are reasonable grounds for questioning the reliability of the information the person has given on his or her age [4]. If the date of birth has not been registered or if the external appearance, behavior, or linguistic expression arouses suspicion of an older person, forensic age assessment is triggered by the previously mentioned immigration authorities.

The forensic age assessment is always performed by two experts who will jointly sign the statement, and at least one of them must be an employee of the Department of Forensic Medicine. An expert may be a certified medical practitioner or a certified dentist with the necessary competence in forensic odontology. Actions required for the examination may also, at the request of the University of Helsinki, Department of Forensic Medicine, be performed by central hospitals, municipal health centers, or private health care units. Persons performing actions necessary for the examinations shall be health care professionals.

For the purpose of the examination, an official from the police, border guard, or the Finnish Immigration Service shall establish the identity of the person to be examined. The parent, guardian, or other legal representatives of the person to be examined has the right to be present when the examination is performed. The person has to give his/her written consent for the radiographic and other examinations, and if registered under 18, an approval of the District Court imposed representative is required. Before obtaining the consent, the applicant and the applicant's guardian or other legal representatives shall be given information on the importance of age assessment, the examination methods used, potential health effects, and the consequences of undergoing, and of refusing, an examination. Anyone who refuses to undergo an examination is considered an adult if there are no reasonable grounds for refusal. On the other hand, refusal to undergo examination does not constitute grounds for rejecting an application for international protection. The information shall be given by immigration authorities and if necessary with an interpreter present, in the native language of the applicant or in a language that he or she may reasonably be expected to understand [4].

According to Radiation Act (592/1991) and the amendment of the Act (1142/1998 Chapter $1039 \S)$, the forensic odontologist evaluates the legitimacy of the medical imaging (ionizing radiation) techniques used during the forensic procedure [6]. If the medical practitioner is not performing the procedure, an educated medical professional can conduct it under his or her supervision. The exposure caused by the use of radiation must be kept as low as reasonably achievable in order to obtain the intended result of the examination [7]. The Ministry of Social Affairs and Health may authorize Radiation and Nuclear Safety Authority (STUK) to issue restrictions governing the use of radiation and recommendations concerning the methods of radiological examination [8].

Act on the Status and Rights of Patients (785/1992) and the amendment of the Act (653/2000) determine the acceptable ways to save and store the information as well as confidentiality of the information in patient documents [9]. Coercive Measures Act (806/2011) and the amendments of the Act (1146/2013) define inspection of a person suspected for a crime [10]. A written indication for person's inspection must be given by the police authority.

The Convention on the Rights of the Child [11] is the first legally binding international instrument to incorporate the full range of human rights - civil, cultural, economic, political, 
and social rights. In 1989, world leaders decided that children needed a special convention just for them because children often need special care and protection that adults do not. The convention deals with the child-specific needs and rights and requires that states act in the best interests of the child. It does not, however, address the situation where minority is disputed and does not refer to the critical issue of age assessment procedures and necessary guarantees in these procedures [12].

\section{The methods of forensic age assessment used in Finland}

The examinee is first interviewed by a forensic odontologist at the Department of Forensic Medicine, University of Helsinki, or if the examination takes place in other parts of Finland, in local central hospitals or municipal health centers before radiographs are taken. The sex, ethnical background, and the examinee's reported age are recorded as well as any nutritional or medical information related to growth. Information of siblings and their age is asked. The weight and height are measured.

The forensic age assessment relies on radiological methods. The STUK has issued a special permit to the Department of Forensic Medicine of the University of Helsinki, allowing the use of ionizing radiation for nonmedical purposes. The modalities allowed by STUK for forensic age assessment include radiographic examinations of the dentition and hand and wrist [5]. The examination usually includes a dental panoramic tomogram and an X-ray of the left wrist. Sometimes when all the permanent teeth including the third molars have completed root formation, periapical intraoral X-rays are needed, for instance in cases where the age of an adult asylum seeker was incorrectly evaluated on arrival $[13,14]$. The radiographs are independently studied by two forensic odontologists who will both sign the joint report.

The references for dental development are chosen after the interview and the radiographic examinations. In some dental development tables, ethnical background is a factor. The maturity of the permanent teeth is decisive for the choice of method. For those with uncompleted development of teeth anterior to third molars, reference tables of Nyström et al. [15], Kataja et al. [16], Chaillet et al. [17], and Willems et al. [18] are used in combination, using three methods for each case. All these are based on Demirjian's staging technique [19]. Tables by AlQahtani include all the permanent teeth [20]. When all the other permanent teeth except third molars are fully developed, staging of third molar development is the most common method for age assessment. The references used are Mincer et al. [21], known as the A.B.F.O. method, based on American and Afro-American research population, and Orhan et al. [22], which is based on Turkish population, as well as tables by AlQahtani [20]. All these references are used in cases where third molars are present. Based on gradual diminution of the size of the dental pulp due to secondary dentin formation, an adult's age can be estimated on a fairly large scale using the method described by Kvaal et al. in intraoral periapical X-rays [23].

Concerning all the examinees from the X-ray of the left hand, wrist, and fingers, bone age is estimated by comparison with the atlas of Greulich and Pyle [24]. The minimum age for complete skeletal maturation of the distal forearm and hand skeleton as seen from a standard hand X-ray is 16 years for both sexes [25]. Ethnicity, malnutrition, and severe illnesses as well as individual variation can affect bone maturation, and this must be taken into account when estimating the bone age. Malnutrition may retard development, and illnesses can either retard or, more rarely, accelerate bone age either directly or through their medical care. For instance, growth hormone accelerates and cortisone retards bone development [26-33].

When hand and wrist bones are fully matured, all teeth anterior to the third molars are completed (Demirjian stage $\mathrm{H}$ ), and the roots of the lower third molars are near to completion (stage G) [19], the forensic age assessment report states that the probability of the individual to have reached the age of 18 in an American male sample would be $56 \%$ [21]. Means and standard deviations of references are included $[21,22]$. When the notified age is for instance 16 years, the report states that the notified age is within possible limits, and the examinee is considered a minor. When also the wisdom teeth are fully developed (stage H) [19], the probability of majority is $90.1 \%$ according to the same reference [21], and with a great probability, the person is considered an adult [20-22].

\section{Results}

\section{The number and frequency of forensic age assessments in Finland}

The number of asylum-seeking minors has varied in Finland from year to year and has thus far reached the peak in 2015, with an obvious rise in the number of forensic age assessments (Table 1). In 2015, the number of asylum seekers was altogether 32,476, unaccompanied minor asylum seekers among them were 3024 [34], and the quantity of forensic age assessments performed was 149 . During the last years, roughly one third of asylum-seeking minors have been sent by the authorities to forensic age assessment. In 2015, however, the actual number of assessments increased notably, but at the same time, the relative proportion dropped to $5 \%$ (Table 1 ). The 149 asylum-seeking minors that underwent forensic age assessment in 2015 originated in altogether 11 countries, most often in Afghanistan, Iraq, and Somalia (Table 2). 
Table 1 Numbers of asylum seekers, unaccompanied minor asylum seekers, and forensic age assessments in Finland in 2005-2015

\begin{tabular}{lccc}
\hline Year & $\begin{array}{l}\text { Asylum } \\
\text { seekers } \\
\text { (total) }\end{array}$ & $\begin{array}{l}\text { Unaccompanied } \\
\text { minor asylum seekers } \\
\text { (\% of total) }\end{array}$ & $\begin{array}{l}\text { Forensic age } \\
\text { assessments } \\
\text { (\% of the minors) }\end{array}$ \\
\hline 2005 & 3574 & $220(6)$ & $0(0)$ \\
2006 & 2324 & $108(5)$ & $15(14)$ \\
2007 & 1505 & $98(7)$ & $9(9)$ \\
2008 & 4035 & $706(17)$ & $7(1)$ \\
2009 & 5988 & $557(9)$ & $133(24)$ \\
2010 & 4018 & $329(8)$ & $83(25)$ \\
2011 & 3088 & $150(5)$ & $69(46)$ \\
2012 & 3129 & $167(5)$ & $55(33)$ \\
2013 & 3238 & $156(5)$ & $52(33)$ \\
2014 & 3651 & $196(5)$ & $70(36)$ \\
2015 & 32,476 & $3024(9)$ & $149(5)$ \\
\hline
\end{tabular}

\section{Results of the forensic age assessments in Finland}

Of those that were examined in $2015,60 \%$ (90/149) were assessed to be aged 18 years or over (Tables 2 and 3). In 41 (28\%) cases, both the notified age and the estimated age were under 18 years (Table 3). The result was inconclusive in 16/149 $(11 \%)$ of the cases (Table 3 ). In these cases the teeth anterior to third molars were fully developed and the skeletal development of hand and wrist bones was completed, but all third molars were either missing or represented a position, in which developmental stage was impossible to evaluate. According to the Finnish Immigration Service authorities, refusal of forensic age assessment among the asylum-seeking minors is practically non-existent even though it is not recorded.

Table 2 Forensic age assessments of unaccompanied minor asylum seekers in 2015 in Finland

\begin{tabular}{lcc}
\hline Nationality & $\begin{array}{l}\text { Number of forensic } \\
\text { age assessments }\end{array}$ & $\begin{array}{l}\text { Assessed } \\
\text { age } \geqq 18 \text { years }\end{array}$ \\
\hline Afghanistan & 84 & 56 \\
Algeria & 1 & 1 \\
Cameroon & 1 & 1 \\
Congo $^{\text {a }}$ & 2 & 1 \\
Gambia & 2 & 1 \\
Guinea & 1 & 1 \\
Iraq & 29 & 10 \\
Mali & 2 & 1 \\
Morocco & 1 & 0 \\
Somalia & 25 & 18 \\
Syrian Arab Republic & 1 & 0 \\
In total & 149 & 90 \\
\hline
\end{tabular}

${ }^{\mathrm{a}}$ The Democratic Republic of the Congo
Table 3 Forensic age assessments among unaccompanied minor asylum seekers in Finland in 2015

\begin{tabular}{ll}
\hline & $\begin{array}{l}\text { Number } \\
\text { of individuals (\%) }\end{array}$ \\
\hline $\begin{array}{l}\text { Notified age and the result } \\
\text { of the age assessment }<18 \text { years }\end{array}$ & $41(28)$ \\
$\begin{array}{l}\text { Notified age }<18 \text { and the result } \\
\text { of the age assessment } \geqq 18 \text { years }\end{array}$ & $90(60)$ \\
$\begin{array}{l}\text { Notified age }>18 \text { and the result } \\
\text { of the age assessment } \geqq 18 \text { years }\end{array}$ & $2(1)$ \\
$\begin{array}{l}\text { Inconclusive result } \\
\text { Forensic age assessments in total }\end{array}$ & $16(11)$ \\
\hline
\end{tabular}

${ }^{a}$ All third molars were either missing or represented a position, in which developmental stage was impossible to evaluate

\section{Discussion}

Previously, the process of forensic age assessment was not defined by legislation, which caused problems. The Minister of Interior consulted the Parliamentary Ombudsman, and based on the statement of the latter in the summer of 2009 , the forensic age assessment was included in the amendment of the Alien Act that was enacted in 2010 [4]. The Convention on the Rights of the Child 1989 states that children have the right for protection [11]. The rights of the child are respected in the national legislation, since the minor asylum seeker is always accompanied with a District Court ordered guardian, who attends to benefits of the child. On the other hand, the law protects the legal rights of forensic odontologists. The two specialists make independent evaluations but sign the statement together. In the criminal context, when age assessment is needed, Coercive Measures Act (806/2011) and the amendments of the Act (1146/2013) are applicable [10].

There is no exact data of refusal of forensic age assessment. A few cancelations have been made by the authorities, but the reason is unknown. Some of the minor asylum seekers are known to disappear from the reception centers. The reason for refusal could be related to the physical or psychological health of the person or to previous traumatizing experience causing fear of the examination. The meaning of a written consent could be criticized, since anyone who refuses to undergo an examination without reasonable grounds for refusal is considered an adult. The consent is, however, a prerequisite for the radiological examination, and the possible health risks are explained before signing.

In some cases, the treating dentist may be questioning the age of an immigrant and ask for a forensic age assessment but the Finnish legislation [4] exclusively lists the authorities - the police authorities, the frontier guard authorities, and the immigration authorities - that have the right to refer asylum seekers to age assessment. Nevertheless, according to the National Supervisory 
Authority for Welfare and Health, health care professionals can transfer a request of an age assessment for the abovementioned authorities, provided a written consent has been obtained of the patient and her/his legal guardian [35].

The text in the Aliens Act states that at least one of the two forensic odontologists performing forensic age assessment must work in the Department of Forensic Medicine of Hjelt Institute (of the University of Helsinki). Hjelt Institute was abolished in the organizational change in January 2015, but the assessments have continued at the University of Helsinki. In January 2017, the law will be amended, transferring the responsibility of forensic age assessment to the National Institute for Health and Welfare (THL) by the request of the Finnish Immigration Service. At least one of the specialists must be employed by THL [4].

In different countries even within Europe and the EU, the methods for forensic age assessment vary, although many other aspects of the asylum-seeking process are regulated by international acts [36-38]. Each member state may decide, how to transpose this aspect of the respective directives into national legislation. Section 6a and $6 \mathrm{~b}$ of the Finnish Aliens Act 2010 implemented the respective regulations of EU-Procedure Directive 2005 Article 17 para 5 [39] into the Finnish legislation, as there are for instance the "ultima ratio" principle of medical expert opinion for asylum-related age assessment, informed consent, and the assignment of qualified medical professionals. The STUK provides that the radiographs of the forensic age assessment must be stored for possible dental treatment, and the examinee must be informed [5]. In Germany, there are three legal contexts allowing forensic age assessment including ionizing imaging: Residence Act 2007, Social Code Book VIII 2015, and for criminal proceedings [39, 40]. Also in Austria, the issue has been regulated in detail since 2010 for all age disputes affecting aliens [41]. Many countries, however, lack the legislation concerning forensic age assessment [36].

In forensic age assessment, radiological examination includes the assessment of the development of the hand and wrist. This method has been criticized, since the reference material was collected already in the 1930s and 1940s and is based on North American population [24, 36]. The recent study of Varkkola and co-workers, where they examined the $\mathrm{X}$-rays of the left wrist of the Finnish tsunami children victims, showed, however, that Greulich and Pyle atlas can be applied even today [42]. Moreover, the study of van Rijn et al. from 2001 [43] confirmed its applicability in Dutch Caucasian children and adolescents. Skeletal maturity, however, may vary due to ethnicity, malnutrition, and severe illnesses [26-29, 44]. Poor socio-economic status may influence skeletal development though in favor of an applicant [27, 45]. Therefore, forensic age assessment of asylum seekers should not rely merely on skeletal development. Disorders and medications possibly intermingling with somatic development are excluded by anamnestic information in the interview. Physical examination before performing an age assessment of an individual is recommended by Study Group on Forensic Age Diagnostics (AGFAD) [40], but it is not used in Finland.

The dental development is extensively genetically regulated and the influence of external factors is minimal $[28,46]$. Yet, ethnical differences do exist [47], which is always mentioned in the report. Different methods are applied for the assessment of dental development in order to increase the accuracy. The report is elaborated taking into consideration the benefit of the examinee, and the best interest of the child is emphasized. If the result of the age assessment is uncertain or the possibility of age under 18 exists, he/she must be treated as a child. An expert report has to exclude age minority in an individual case beyond reasonable doubt, before age majority is ruled by authorities [48].

In many European countries, sterno-clavicular radiographic imaging is used for age assessment. In Finland, evaluation of clavicular development is not included in the forensic age assessment examination, because of the higher effective radiation doses and the fact that the special permit of STUK allows only dental and hand X-rays for non-medical purposes [5]. According to recommendations by AGFAD, additional radiological examination of the clavicle should be carried out, when the skeletal development of the hand and wrist is completed [49]. Prospective posterior-anterior chest X-rays for the assessment of the clavicular development are no longer recommended for forensic age estimation, because it is often difficult or impossible to assess clavicular staging from it [50] and additional oblique pictures may display different stage impressions in comparison [51]. Thin-slice computed tomography of the clavicle has been suggested instead as the exclusive method of choice [52]. The officials of the Finnish Immigration Service have noticed that recently, it has become increasingly common for the examinees to miss third molars, and it has been discussed, whether clavicular radiological examination should be included in the assessment. Ethical practice in forensic age assessment requires that the main benefit has to outweigh the physical risk (principle of proportionality) and there is a societal benefit resulting from the practice as stated in the Medical Exposure Directive 2013 Art. 5a and 55 para 1 [53]. The best age estimation methods provide an age differentiation along the legally relevant age limit with the required probability, following the principle "in dubio pro minore" providing the best interest of the child [48]. The expertise of the forensic odontologist and calibration of co-examiners is demanded [54].

The number of asylum seekers and unaccompanied minor asylum seekers has risen distinctly during the years 
2005-2015, and the number of forensic age assessments has varied accordingly. Reception centers for asylum seekers are located all over Finland. Sufficient numbers of forensic odontologists in different parts of Finland after the possibility to obtain special competence in forensic odontology since 1999 and the current legal system guarantee a flexible process of forensic age assessment. The problem of not having dental development tables from the original countries of the applicant is always mentioned in the statement, but the recent research implies that the possible error is minimal [47].

In 2015, of those whose notified age was under 18 years, 60\% (90/149) were assessed to be over 18 after the forensic age assessment. The mandate of a forensic odontologist does not include any decision making, and the final decision is made by the authorities. Since sexual maturation or psychological development is not used as a method, the authorities, in practice, make the decision based on the forensic age assessment report and change the age of the asylum applicant accordingly. If the asylum seeker disagrees with the decision, an appeal can be submitted to the District Court, but so far, it has been rare. In cases when all wisdom teeth are missing or in such a position that it is impossible to interpret their radicular development, the result of the forensic age assessment remains inconclusive. In our material, this occurred in $11 \%$ of the cases in 2015. As happened in a few cases in 2015, an examinee referred by the immigrant authorities to forensic age assessment may inform during the interview that he/she is an adult and not a minor as initially claimed. In such rare cases, the forensic age assessment is completed nevertheless, since it is the immigrant authorities to make the decision, who to examine. In some cases, there is suspicion that an adult is actually a minor and therefore sent to forensic age assessment. Wrong age group affiliation may have serious impact, for instance, problems caused by incorrect accommodation of the unaccompanied child with adults in the reception center or vice versa [37]. In $2015,28 \%$ of the examinees were assessed to be under-aged.

\section{Conclusion}

The current legislation on forensic age assessment has been well received in Finland and approved by forensic odontologists and immigration authorities. In changing situations, the legislation should function flexibly, and the legislators should listen to the views of the forensic experts. The aim is to simultaneously guarantee the rights of the individual and the quality and validity of the examination. The immigrant authorities, selecting which persons should be referred to forensic age assessment, carry a great responsibility.
Acknowledgements The authors thank Professor Patrick Thevissen, Department of Oral Health Sciences, Forensic Dentistry, KU Leuven, Belgium, whose suggestions greatly improved the manuscript.

\section{Compliance with ethical standards}

Conflict of interest The authors declare that they have no conflict of interest.

\section{References}

1. The Finnish Immigration Service. http://www.migri. fi/download/43811_43667_Maahanmuuton_tilastokatsaus2012 web.pdf?58bc03b8b8a7d288

2. Eurostat. Asylum statistics. http://ec.europa.eu/eurostat/statisticsexplained/index.php/Asylum_statistics

3. The government's proposal to change Aliens Act (301/2014). http://www.finlex.fi/fi/esitykset/he/2009/20090240.pdf.

4. Aliens Act 301/2004 and the Amendment of the Act 549/2010, Finnish Legislation. http://www.finlex.fi/fi/laki/kaannokset/2004 /en20040301.pdf and http://www.finlex.fi/fi/laki/ajantasa/2004 /20040301

5. Permission1/590/97 for the Department of the Forensic Medicine, University of Helsinki signed by the the General Director Jukka Laaksonen and the Director Heimo Kahlos of the Radiation and Nuclear Safety Authority in September 19th 1997

6. Radiation Act (592/1991) and amendment of the Act (1142/1998 Chapter 10), Finnish Legislation. http://plus.edilex. fi/stuklex/en/lainsaadanto/19910592

7. Decree on use of radiation by the Ministry of Social Affairs and Health (423/2000 8§). http://www.finlex.fi/fi/laki/alkup/2000 120000423

8. Radiation and Nuclear Safety Authority. Reference levels for the patient's radiation exposure for conventional X-ray examinations of adults, Decision 9/3020/2014. https://www.stuk. fi/documents/88234/1106801/decision-9-3020-2014-26-6-2014reference-levels-for-the-patients-radiation-exposure-forconventional-x-ray-examinations-of-adults.pdf/f0b113e1-ba1e-41 c2-9077-1c3229001875

9. Act on the Status and Rights of Patients (785/1992) and the amendment of the Act (653/2000 Chapter 4), Finnish Legislation. http://www.finlex.fi/fi/laki/kaannokset/1992/en19920785.pdf

10. Coercive Measures Act (806/2011) and the amendments of the Act (1146/2013 Chapter $832 \S$ and $33 \S)$, Finnish Legislation. http://www.finlex.fi/en/laki/kaannokset/2011/en20110806.pdf

11. United Nations General Assembly Convention on the Rights of the Child, A/RES/44/25 1989 http://www.un.org/documents/ga/res/44 /a44r025.htm

12. European Migration Network Synthesis Report for the EMN Focussed Study 2014 (2015) Policies, practices and data on unaccompanied minors in the EU Member States and Norway. Synthesis Report: May 2015. http://ec.europa.eu/dgs/homeaffairs/what-we-do/networks/european migration network/reports/docs/emn-studies/emn_study policies practices and_data_on_unaccompanied_minors_in_the_eu_member_states and norway s ynthesis report final eu $201 \overline{5}$.pdf

13. Cameriere R, Ferrante $\bar{L}$ (2007) Canine pulp ratios in estimating pensionable age in subjects with questionable documents of identification. Forensic Sci Int 206:132-135. doi:10.1016 /forsciint.2010.07.025 
14. Sharma R, Srivastava A (2010) Radiographic evaluation of dental age of adults using Kvaal's method. J Forensic Dent Sci 2:22-26. doi:10.4103/2948.71053

15. Nyström M, Ranta H, Peltola J, Kataja M (2007) Timing of developmental stages in permanent mandibular teeth of Finns from birth to age 25. Acta Odontol Scand 65:36-43

16. Kataja M, Nyström M, Aine L (1989) Dental maturity standards in southern Finland. Proc Finn Dent Soc 85:187-197

17. Chaillet N, Nyström M, Demirjian A (2005) Comparison of dental maturity in children of different ethnic origins: international maturity curves for clinicians. J Forensic Sci 50:1164-1174

18. Willems G, Van Olmen A, Spiessens B, Carels C (2001) Dental age estimation in Belgian children: Demirjian's technique revisited. J Forensic Sci 46:893-895

19. Demirjian A, Goldstein H, Tanner JM (1973) A new system of dental age assessment. Hum Biol 45:211-227

20. AlQahtani SJ, Hector MP, Liversidge HM (2010) The London atlas of tooth development and eruption. Am J Phys Anthropol 142:481490. doi:10.1002/ajpa.22473

21. Mincer HH, Harris EF, Berryman HE (1993) The A.B.F.O. study of third molar development and its use as an estimator of chronological age. J Forensic Sci 38:379-390

22. Orhan K, Ozer L, Orhan AI, Dogan S, Paksoy CS (2007) Radiographic evaluation of third molar development in relation to chronological age among Turkish children and youth. Forensic Sci Int 165:46-51

23. Kvaal SI, Kolltveit KM, Thomsen IO, Solheim T (1995) Age estimation of adults from dental radiographs. Forensic Sci Int 74:175-185

24. Greulich WW, Pyle SI (1959) Radiographic atlas of skeletal development of the hand and wrist, Second edn. Stanford University Press, Stanford, California

25. Tisé M, Mazzarini L, Fabrizzi G et al (2011) Applicability of Greulich and Pyle method for age assessment in forensic practice in Italian sample. Int J Legal Med 125:411-416. doi:10.1007 /s00414-010-0541-6

26. Loder RT, Estle DT, Morrison K, Eggleston D, Fish DN, Greenfield ML, Guire KE (1993) Applicability of the Greulich and Pyle skeletal age standards to black and white children of today. AJDC 147: 1329-1333

27. Schmeling A, Reisinger W, Lorek D, Vendura K, Markus W, Geserick G (2000) Effects of ethnicity on skeletal maturation: consequences for forensic age estimations. Int J Legal Med 113:253-258

28. Kullman L (1995) Accuracy of two dental and one skeletal age estimation method in Swedish adolescents. Forensic Sci Int 75: 225-236

29. Ontell FK, Ivanovic M, Ablin DS, Barlow TW (1996) Bone age in children of diverse ethnicity. AJR 167:1395-1398

30. Carel J-C, Lahlou N, Roger M, Chaussain L (2004) Precocious puberty and statural growth. Hum Reprod Update 10:135-147

31. Kamp GA, Waelkens JJ, de Muinck Keizer-Schrama SM, Delemarre-Van de Waal HA, Verhoeven-Wind L, Zwinderman AH, Wit JM (2002) High dose growth hormone treatment induces acceleration of skeletal maturation and an earlier onset of puberty in children with idiopathic short stature. Arch Dis Child 87:215-220

32. Blodgett FM, Burgin L, Iezzoni D, Gribetz D, Talbot NB (1956) Effects of prolonged cortisone therapy on the statural growth, skeletal maturation and metabolic status of children. N Engl J Med 254: 636-641

33. Kerrebijn KF, de Kroon JP (1968) Effect of height of corticosteroid therapy in asthmatic children. Arch Dis Child 231:556-561

34. The Finnish Immigration Service. http://www.migri.fi/about us/statistics/statistics_on_asylum_and_refugees

35. Valvira-National Supervisory Authority for Welfare and Health, Turvapaikanhakijoiden ja pakolaisten iänmääritystä koskevat tutkimukset; terveydenhuollon toimivalta ja terveystietojen salassapito, Directive 13/2010. https://www.valvira. fi/documents/14444/50159/Valvira_ohje_13_2010.pdf

36. Separated Children in Europe Programme (SCEP), Thematic group on age assessment. Position paper on age assessment in the context of separated children in Europe 2012, May 2012. http://umf.asyl. at/files/DOK45Age_Assessment_PP.pdf

37. European Asylum Support Office, EASO Age assessment practice in Europe, Publications Office of the European Union 2014. https://www.easo.europa.eu/sites/default/files/public/EASO-Ageassessment-practice-in-Europe.pdf. doi:10.2847/12152

38. Solheim T, Vonen A (2006) Dental age estimation, quality assurance and age estimation of asylum seekers in Norway. Forensic Sci Int 159S:S56-S60

39. Council Directive 2005/85/EC (2005) EU-Procedure Directive Art. 17 para 5. http://eur-lex.europa.eu/legal-content/EN/ALL/?uri= CELEX\%3A32005L0085

40. Schmeling A, Dettmeyer R, Rudolf E, Vieth V, Geserick G (2016) Forensic age estimation: methods, certainty, and the law. www.aerzteblatt-international.de/ref0416

41. Rudolf E, Kramer J, Gebauer A et al (2015) Standardized medical age assessment of refugees with questionable minority claim - a summary of 591 case studies. Int J Legal Med 129:595-602. doi:10.1007/s00414-014-1122-x

42. Varkkola O, Ranta H, Metsäniitty M, Sajantila A (2011) Age assessment by the Greulich and Pyle method compared to other skeletal X-ray and dental methods in data from Finnish child victims of the southeast Asian tsunami. Forensic Sci Med Pathol 7:311-316. doi:10.1007/s12024-010-9173-x

43. Rijn van RR, Lequin MH, Robben SGF, Hop WJ, Kuijk van C (2001) Is the Greulich and Pyle atlas still valid for Dutch Caucasian children today? Pediatr Radiol 31:748-752

44. Cole TJ, Rousham EK, Hawley NL, Cameron N, Norris SA, Pettifor JM (2015) Ethnic and sex differences in skeletal maturation among the birth to twenty cohort in South Africa. Arch Dis Child 100:138-143. doi:10.1136/archdischild-2014-306399

45. Meijerman L, Maat GJR, Schulz R, Schmeling A (2007) Variables affecting the probability of complete fusion of medial clavicular epiphysis. Int J Legal Med 121:463-468. doi:10.1007/s00414007-0189-z

46. Chaillet N, Willems G, Demirjian (2004) A dental maturity in Belgian children using Demirjian's method and polynomial functions: new standard curves for forensic and clinical use. J Forensic Odontostomatol 22:18-27

47. Thevissen PW, Fieuws S, Willems G (2010) Human third molars development: comparison of 9 country specific populations. Forensic Sci Int 201:102-105. doi:10.1016/j.forsciint.2010.04.054

48. Council Directive 2013/32/EU (2013) EU-Procedure Directive Art. 25 para 5 . http://eur-lex.europa.eu/legal-content/en/ALL/?uri= celex\%3A32013L0032

49. Schmeling A, Grundmann C, Fuhrmann A, Kaatsch H-J, Knell B, Ramsthaler F, Reisinger W, Riepert T, Ritz-Timme S, Rösing FW, Rötzscher K, Geserick G (2008) Criteria for age estimation in living individuals. Int J Legal Med 122:457-460. doi:10.1007/s00414008-0254-2

50. Cameriere R, De Luca S, De Angelis D, Merelli V, Giuliodori A, Cingolani M, Cattaneo C, Ferrante L (2012) Reliability of Schmeling's stages of ossification of medial clavicular epiphyses and its validity to assess 18 years of age in living subjects. Int $\mathbf{J}$ Legal Med 126:923-932. doi:10.1007/s00414-012-0769-4

51. Wittschieber D, Ottow C, Vieth V, Küppers M, Schulz R, Hassu J, Bajanowski T, Püschel K, Ramsthaler F, Pfeiffer H, Schmidt S, Schmeling A (2015) Projection radiography of the clavicle: still recommendable for forensic age diagnostics in living individuals? Int J Legal Med 129:187-193. doi:10.1007 /s00414-014-1067-0 
52. Kellinghaus M, Schulz R, Vieth V, Schmidt S, Schmeling A (2010) Forensic age estimation in living subjects based on the ossification status of the medial clavicular epiphysis as revealed by thin-slice multidetector computed tomography. Int J Legal Med 124:149154. doi:10.1007/s00414-009-0398-8
53. Council Directive 2013/59/EURATOM (2013) EU-Medical Exposure Directive Art. 5 and 55 para 1. http://eur-lex.europa. eu/legal-content/EN/TXT/?uri=CELEX:32013L0059

54. Thevissen PW, Kvaal SI, Willems G (2012) Ethics in age estimation of unaccompanied minors. J Forensic Odontostomatol 30S:84-10 